\title{
Evaluating McCallum Rule as Policy Guideline for China
}

\author{
Shuzhang Sun; Christopher Gan; Baiding Hu \\ Lincoln University \\ 643 3252811; shuzhang.sun@lincolnuni.ac.nz
}

\begin{abstract}
Economists have reached a consensus that central bank could improve its policy efficiency by following a monetary policy rule. Given that money supply is the People's Bank of China (PBC) principal policy instrument and its monetary targeting regime, this paper utilizes counterfactual simulation method to evaluate the feasibility of McCallum rule as a policy guideline for China in two simple macroeconomic models. The simulation results show that following McCallum rule could significantly reduce China's nominal GDP fluctuations. The analysis shows that rule-specified path for the monetary base changes could be used as a benchmark for PBC's policy decision.
\end{abstract}

JEL classifications: E42, E52

Key words: McCallum rule; PBC’s Policy guideline; Counterfactual simulation method

\section{Introduction}

The long-run objectives of monetary policy are low inflation and stable growth of real output at full employment. The question on how a central bank fulfills its long-run monetary policy objectives, whether following a policy rule or with discretion has been debatable since Simons' seminal paper in 1936. Research in macroeconomics provides many reasons why monetary policy should be evaluated and conducted as a policy rule rather than as a onetime change in policy. First, the literature on time-inconsistency shows that without commitment to a rule, policymakers will be tempted to choose a suboptimal inflation policy that will result in a higher average inflation rate and no lower unemployment than if a rule is followed in choosing a policy (see Kydland and Prescott 1977; Barro and Gordon 1983). Second, credibility about monetary policy appears to improve its performance; sticking to a policy rule increases the credibility about future policy action. In addition, policy rules help market participants forecast future policy decisions and therefore reduce uncertainty. Policy rules increase accountability and potentially require policymakers to account for the difference between their actions and the rules (Taylor, 1998). The well-known simple policy rules ${ }^{1}$ in

\footnotetext{
${ }^{1}$ The simple policy rules refer to simple feedback instrument rule, relative to fully optimal rules derived from the first order conditions of the central bank's welfare maximization subject to the economic situation in which the monetary policy rule operates (Kalin 2002).
}

the past decades are Taylor and McCallum rules following the non-active constant growth rate rule supported by Friedman (1959) and Lucas (1980). A major advantage of McCallum rule over Taylor rule is that McCallum rule does not include unobservable variables such as the real interest rate and the output gap.

McCallum rule is much less prominent than Taylor's rule, primarily because central banks in industrial countries focus on interest rate instead of monetary base growth rates in designing their policy (McCallum, 2002a). The new Keynesian Taylor rule noted that a central bank follows an interest rate target and ignores monetary aggregate (Cochrane, 2007). McCallum rule is a nominal income target rule with a monetary base as its policy instrument.

Taylor (2000a) claims that a monetary base or some other monetary aggregate can still be a reasonable monetary instrument in emerging economies. Beck and Weiland (2008) also support the importance of a monetary base variable in policy-making. In regards to the feasibility of adopting monetary policy rules in emerging economies, Meltzer (1995) and Taylor (2000) state that policy rules are applicable both to countries with and without developed financial markets. Since money supply is still a dominant policy instrument under the monetary targeting regime in China, the McCallum rule appears to be an appropriate choice for China's central bank. Using the counterfactual simulation method, supplemented by historical analysis method, this study investigates whether the McCallum 
rule can be a useful policy guideline for China's central bank to improve its policy performance.

The rest of this paper is organized as follows. The next section reviews the principles of McCallum rule and its improvements. Section 3 describes the counterfactual simulation method and section 4 discusses the data sources. Section 5 reports the empirical results and section 6 concludes the paper.

\section{Principles of McCallum Rule}

McCallum (1987, 1993, 2006) advocates a policy rule for central banks to follow in setting monetary policy. The rule, developed outside the confine of a single model, would work well with different economic models, since it is free from the model-specific problem. Since macroeconomists disagreed about the forces that drive the economy, they are unlikely to come up with an optimal rule for the operation of the monetary policy (Stark, 1996). McCallum rule requires central banks to target the growth rate of nominal GDP using the monetary base as its instrument.

According to McCallum (1984, 1985, 1987), four principles should be followed in designing a monetary rule. First, the rule should dictate the behavior of a variable that the monetary authority can control directly and/or accurately. Second, the rule should not rely on the presumed absence of regulatory changes and technical progress in the financial industries. Third, neither money stock nor (nominal) interest rate paths ${ }^{2}$ are important for their own sake; these variables are relevant only to the extent that they are useful in facilitating good performance in the magnitudes of inflation and output or employment. Fourth, a well-designed rule should recognize the limits of macroeconomics knowledge. In particular, it should recognize that neither theory nor evidence points convincingly to any of the numerous competing models of the interaction of nominal and real variables.

Based on the four principles, McCallum (1987) specifies a target path for nominal GDP using the monetary base as the operational mechanism, a variable that can be accurately set on a daily basis by the central bank with a floating exchange rate. Specifically, the rule "would adjust the base growth rate each month or quarter, increasing the rate if nominal GDP is below its target path and vice versa" (McCallum, 1984, p. 390). In 1993, McCallum

\footnotetext{
${ }^{2}$ In Macroeconomics, the word "path" describes the locus of a variable changes over time.
}

revised the rule using the nominal GDP growth rate instead of the nominal GDP as the target, supported by Stark and Croushore (1996). In algebraic form, the McCallum rule is:

$\Delta B_{t}=\Delta X_{t}^{*}-\Delta V B_{t}+\lambda\left(\Delta X_{t-1}^{*}-\Delta X_{t-1}\right)$

Where all the variables are in logarithms, $B$ is the monetary base, $\Delta V B$ is the average base velocity growth rate over the previous four years, $\lambda$ is the monetary response factor, and $X$ is the log of nominal GDP. The asterisk (*) denotes the target growth rate, which is the sum of the inflation rate and the long-run average real GDP growth rate.

The growth of the monetary base is determined by the three terms on the right-hand side of equation (1). The first term sets the monetary base growth rate equal to the desired rate of inflation plus the potential or desired real GDP growth rate. McCallum emphasized real, since outputs and employments levels over longer spans of time will be independent of the average growth rate of the nominal variables (McCallum 1988, p.175). The second term on the right-hand side of equation (1) is the growth rate of monetary base velocity, which reflects the impact of technological and regulatory changes on the velocity of the monetary base. In this regard, McCallum rule forecasts the average growth rate of velocity over the future. This term helps to prevent the price level from drifting in response to a permanent shock to money demand. With the velocity growing at a steady-state rate and the nominal GDP growth rate equal to its target, the rule forces the inflation rate to remain at a desired level, assuming that the monetary policy is neutral in the long run. The last term on the right-hand side of equation (1) is the most important term for stabilization of output and price level, which suggests the monetary policy authority to adjust monetary base growth whenever the nominal GDP growth rate differs from its target. When the nominal GDP growth rate is below its target, the monetary authority should temporarily increase monetary base growth and vice versa.

The first feature of the McCallum rule prefers nominal GDP to monetary aggregates such as M1 or M2, as the monetary authority's principal target variable. Monetary aggregates have become unreliable guides and the nominal GDP correlates with the real GDP and inflation. In addition, the nominal GDP has two other features that would make it a good guide for policy in principle. First, under the nominal GDP targeting, the monetary policy would adjust to offset disturbances to 
aggregate demand. A second attractive feature of the nominal GDP targeting is that it would help the policy maker balance the goals of stable output growth and inflation in response to aggregate supply disturbance (Clark, 1994). Furthermore, the nominal GDP is preferred to real GDP as the policy target because a central bank cannot control or predict with accuracy how the nominal GDP growth divides on a quarter-by-quarter basis between real growth and inflation (McCallum, 1988).

The second feature of McCallum rule is the specification of a constant growth target for nominal income, rather than a target rate that varies over the cycle. In this way, it would at least eliminate policy surprises as a source of undesirable fluctuations arising from the central bank's pursuit of an optimal policy decision. The third feature of McCallum rule is to utilize monetary base instead of interest rate as a monetary policy instrument. McCallum in his 1993 paper discussed in detail the reasons why he prefers monetary base to interest rate as a policy instrument. McCallum argues that if the nominal interest rate is use as an indicator of monetary policy stance, then tightening or easing the policy stance results in ambiguity. In this regards, the rule is desirably operational, since the central bank is capable of controlling the monetary base variable with accuracy.

A technical issue regarding McCallum rule is whether the behavior of the base growth target specified by the rule is permissible for the base growth to be of use in practice. McCallum (2006) suggests using the average nominal GDP growth over the past 4 quarters instead of the most recent quarter for the rule's final term (this is analogous to the Taylor rule's use of an average four-quarter inflation rate value). The McCallum rule that uses the average nominal GDP growth over the past four quarters for the final term is refer as the improved (McCallum) rule in this study. We evaluate the original and improved McCallum rule separately.

Several studies have used the counterfactual or stochastic simulation method to test the robustness of McCallum's rule. Based on seasonally adjusted US quarterly data for 1954Q1 - 1985Q4, McCallum (1988) verified the rule using two single equation models, regressing nominal income growth rate on the current or one-period lagged monetary base growth rate, and one-period lagged nominal income growth rate. However, these two single equation models used to depict nominal income determination are simple and likely to be policy invariant. McCallum further verified the robustness of his simple rule to an atheoretic VAR model and structural classical and Keynesian slant model. The simulation results show that adherence to monetary basegrowth rates specified in equation (1) would have yielded essentially the desired inflation, despite the financial and regulatory changes during the testing period, while reducing the extent of cyclical fluctuation in nominal income. In McCallum's latter papers (1993, 1999, 2000), similar models were used to further verify the robustness of the rule based on data from different countries. In these papers, McCallum adopted a nominal target of the growth-rate type, rather than the growinglevel type used in his prior research. The main disadvantage with a level-type target path is that the target variable is revert back to the preset path after any disturbance that has driven it away, even if the effect of the disturbance is of a permanent nature. Since such an action entails general macroeconomic stimulus or restraints, this type of targeting procedure would tend to induce extra cyclical variability in demand conditions, which implies extra variability in real output if price level stickiness prevails (McCallum, 1999, p. 1498).

Hall (1990), Judd and Motley (1991, 1993), Dueker (1993), Stark and Croushore (1996), Philip (2000), and Razzak (2003) present supportive evidence of McCallum rule based on data from different developed countries using simulation methods. Stark and Croushore (1996, p. 3) in their study encourage researchers to use models in which monetary policy has real effects. For this reason, they excluded the real business cycle models and rational expectations models from this study because the real effects of monetary policy in these models tend to be nonexistent or very small. . Stark and Croushore (1996) examine the effectiveness of McCallum rule using a Keynesian model, a reduced form model and a structural VAR model. They conclude that McCallum rule is a potentially useful rule for setting monetary policy.

The historical analytical method developed by Stuart (1996) and Taylor (1999) consist of contrasting actual setting of instrument variables during some historical time span with the values specified by particular rules in response to prevailing conditions. Discrepancies or agreements between rulespecified and the actual values can then be evaluated in light of ex-post judgments concerning the merit of the various rules. Stuart (1996) compared McCallum rule with the monetary policy decisions based on a thorough assessment of the prospect for 
inflation using UK data for the period 1985Q11962Q2. The author found that the simple rule provides information about inflation and economic activity, which can be used with other relevant information in the formulation of monetary policy.

Taylor (1999) examines the US monetary history for two different periods: 1880-1914 versus 1955-1997, using the framework specified by Taylor rule. The author concludes that the historical approach to monetary policy evaluation complements the model-based approach and that case studies are useful for judging how much discretion is appropriate when a policy rule is use as a guideline for central bank policy decisions. McCallum (2000) follow Stuart-Taylor method on the US and UK from early 1960s to 1998 and for Japan from 1970s extending through 1998. McCallum concludes that the Stuart-Taylor method can also be a useful approach to McCallum rule evaluation in addition to simulations with structural models.

McCallum rule is currently less popular than Taylor rule in developed countries, but it has attracted attention of some researchers who have great interest in China's monetary policy. Some researchers have tried to test McCallum policy rule to identify a guideline for the People's Bank of China (PBC). For example, Burdekin and Siklos (2005) apply McCallum rule to model Chinese monetary policy using the coefficient specified by McCallum and then allowing the data to determine the coefficient estimates. Based on the simulated values for the nominal GDP growth rate, the authors concluded that the PBC had appeared to response to the gap between the target and the actual nominal GDP and China's inflation and monetary policy outcomes could be satisfactorily modeled using standard empirical techniques instead of a figment of Chinaspecific "structural" factors. However, Liu and Zhang (2007) compare the fit of the modified McCallum rule using monetary base or M2 as the dependent variable with the actual realized values for money supply. The authors conclude that a quantity of money rule in the spirit of McCallum could not depict the PBC's policy stance adequately.

Following the estimation of the standard McCallum rule and a modified McCallum rule, Kong (2008) concludes that the two estimated McCallum rules reflect the trend of the actual base money growth rate,. Thus, it is useful to utilize the McCallum rule as a guideline for China's monetary policy. Tuuli et al (2008) analyze China's monetary policy after 1994 using a quantity-based McCallum rule. By testing the excess money supply (deviation of the actual money supply growth from the value given by McCallum rule), the authors suggest that the McCallum rule can be a useful tool for analyzing the monetary policy stance and for providing information about inflationary pressures in the Chinese economy.

However, some unaddressed issues remain in these studies. First, Liu and Zhang (2007) and Tuuli et al, (2008) studies adopted the McCallum's specified coefficient value of 0.5 for the monetary response factor based on the Japanese data for the period 1972-1992. In addition, a 4 percent long-term average annual growth rate of real output is used as the target growth rate in the rule when conducting the simulation to decide on the coefficient value (McCallum 1993). On the other hand, McCallum rule coefficient value of 0.25 is base on the US data for the period 1954:Q11985:Q4. A three percent long-term average annual growth rate of real output is used as the target growth rate in the rule when identifying the coefficient value (McCallum 1987, 1988). Therefore, to test the validity of McCallum rule using Chinese data, a researcher should take into account the variation in the value for $\lambda$. Second, Kong (2008) evaluates a modified McCallum rule, with the inflation gap (the difference between inflation target and realized value) added into the rule as an independent variable. However, the author neglected the fact that the feedback term defined in McCallum rule is the nominal GDP growth which gives equal weight to changes in the real output gap and deviations of inflation from the target. Furthermore, Tuuli et al (2008) uses $M_{2}$ as the dependent variable to test the effectiveness of McCallum rule in China. This ignores the fundamental principle of McCallum rule that the instrument variable should be under the central bank's direct control.

\section{Simulation Procedure and Macroeconomic Condition Model}

Following McCallum (1987, 2002a), this study utilizes counterfactual simulation method to evaluate the feasibility of McCallum rule to achieve a nominal GDP growth rate target in China. If the application of the rule in place of actual historical policy yields smoother nominal GDP paths than those actually experienced, we can conclude the rule perform well. In order to calculate the performance of the McCallum rule in minimizing deviations around a given target path for nominal GDP, we need to specify the macroeconomic conditions in which the policy rule will work. 
McCallum (1988, 1993) and Stark and Croushore (1996) documented the robustness of the rule by testing it across different models. The simple reduced-form type models used by McCallum (1988, 1993, 2002a) provided the results that are quite comparable to those produced with small but somewhat more complex structure models used in his studies. Additionally, Hall (1990), Hafer et al (1991, 1996) and Philip (2000) used the single equation models to evaluate McCallum rules.

In this study, we first replicate a single equation macroeconomic model used by McCallum (2002a) that specifies the relationship between the nominal GDP growth and monetary base growth. This model provides a basic macroeconomic condition to evaluate the possible effectiveness of McCallum rule using China's data. The model is given as follows:

$\Delta X_{t}=\beta_{0}+\beta_{1} \Delta X_{t-1}+\beta_{2} \Delta X_{t-2}+\beta_{3} \Delta B_{t-1}+\varepsilon_{1 t}$

Where $X_{t}$ and $B_{t}$ denote logarithms of the nominal GDP and the monetary base, respectively. $\Delta X_{t}$ and $\Delta B_{t}$ are quarterly growth rates. $\varepsilon_{1 t}$ is disturbance term.

To avoid the reverse-causation problem, equation (2) excluded the $\Delta B_{t}$ term (Sims, 1980; King and Plosser, 1982). This method avoids the real sector that drives the monetary sector, in contrast to the traditional view of monetary movements as business cycle impulse. Furthermore, it is common that monetary policy operates with variable lags on the economy (Blinder, 1998, p.13). Equation (2) introduces a full two-quarter lag between the target departures $\Delta X_{t-1}^{*}-\Delta X_{t-1}$ and corrective effects, which reflect the causal direction. Before conducting the simulation, we first estimate the parameters and residuals of equation (2) over the study period, with the residuals capturing shocks to the economy. Then, we use the McCallum rule given by equation (1) and the initial actual values of GDP growth and monetary base growth to determine a simulated value for monetary base growth. With a simulated monetary base growth, we can then use equation (2) to obtain a simulated value for nominal GDP, which feed into the equation. The root-meansquared-error (RMSE) is used to measure the deviations of the simulated and actual values of the nominal GDP from the targets. The RMSE is given as follows:

$$
R M S E=\sqrt{\sum\left(\Delta X_{t}^{*}-\Delta X_{t}\right)^{2} / n}
$$

A floating exchange rate regime is necessary in McCallum's view for the monetary policy rule to work effectively (1987, p. 13). Given China's managed floating exchange rate regime, we extend equation (2) by adding an exchange rate variable to test the rule's robustness, namely,

$$
\begin{aligned}
\Delta X_{t}= & \beta_{0}+\beta_{1} \Delta X_{t-1}+\beta_{2} \Delta X_{t-2}+\beta_{3} \Delta B_{t-1} \\
& +\beta_{4} \Delta S_{t-1}+\varepsilon_{2 t}
\end{aligned}
$$

Where $S_{t}$ denotes the log of the real effective exchange rate, with an increase in $S_{t}$ implying a devaluation of the Chinese currency.

\section{Data and Methodology}

Data used in this study include GDP target and real effective exchange rate covering 1994:Q1 to 2009:Q1, and monetary base and nominal GDP covering 1990:Q1 to 2009:Q1. We choose 1994 as the starting year since the third phrase of China economic reforms where the official and market exchange rates were unified and current account transactions were liberalized. In addition, the banking reform included the establishment of three policy (non-commercial) banks and separating policy finance from more commercially oriented activities. In the same year, the PBC started the monetary targeting regime - using M2 as the intermediate target.

To construct the time series for $\Delta V B$ (average value of previous four years) starting from 1994:Q2 ( $\left.V B=N G D P / M B{ }^{3}\right)$, we use the monetary base and nominal GDP data from 1990:Q1. However, officially released quarterly data for monetary base is only available from 1993:Q1 (The People's Bank of China Quarterly Statistical Bulletin). Therefore, we utilize annually data for monetary base and M1 from International Financial statistics (IFS) to calculate the money multiplier for the period 1990-1992. Based on the obtained money multiplier and officially released quarterly data for M1 from 1990:Q1 to 1992:Q4, we obtained the quarterly data for the monetary base from 1990:Q1 to 1992:Q4.

Another important time series in McCallum rule is the nominal GDP target but is unavailable for China since the Chinese government only released the annual real GDP target instead of annual nominal GDP target. McCallum used the sum of the average longrun real GDP growth rate and the target inflation rate as a proxy for the nominal GDP

\footnotetext{
${ }^{3}$ NGDP and MB stand for nominal GDP and Monetary base in level.
} 
target. In China, the government announces a real GDP target and a RPI or CPI inflation target every year in the Report on the implementation of the plan for National Economic and Social Development and on the Protocol for National Economic and Social development. Although the RPI or CPI inflation rate is not exactly equal to the GDP deflator inflation rate, we preferred the former to the latter, since the GDP deflator is a realized value not a target value. Furthermore, we do not know how current changes in GDP divide into the GDP deflator and real output growth. Before 1997, the Chinese government announced a RPI inflation rate target instead of the CPI inflation rate target, and started to announce a RPI and CPI inflation target rate simultaneously between 1998 and 2000. The annual CPI inflation target rate, which only became available from 2001, exceeded the annual RPI inflation target rate for the same period by two percent.

To construct a complete time series for CPI inflation target, we add two percentage points onto the RPI inflation target rate for 1994-1997 to approximate the CPI inflation target values for the period. Following this, we add the CPI inflation target rate to the officially announced real GDP target growth rate to obtain a time series for the annual nominal GDP growth rate target. The annual values for the nominal GDP growth target rate are interpolated into quarterly values using the following formula:

$Q r=(1+a r)^{1 / 4}-1$

Where ar denotes annual growth rate and $Q r$ is the interpolated quarterly growth rate.

Data on the exchange rate (quarterly average real effective exchange rate) is obtain from the Bank for International settlement (BIS) monthly average real effective exchange rate using the simple average method with the year 2005 equal to 100.

Before estimating equations (2) and (3), we first perform the unit root test for the time series variables to avoid spurious regressions. The results of Augmented Dicker-Fuller (ADF) for monetary base growth rate $(\Delta B)$, monetary base velocity change rate $(\Delta V B)$, nominal GDP growth rate $(\Delta X)$, real effective exchange rate change rate $(\Delta S)$ and Phillips-Perron (PP) test for $\Delta B$ and $\Delta V B$ are reported in Table 1 . The ADF- test results show that $\Delta X$ and $\Delta S$ are stationary at $1 \%$ level, while $\Delta B$ and $\Delta V B$ are stationary at $10 \%$ and $5 \%$ level respectively. We also conduct a PP unit root test for the variables and the results show they are stationary at $1 \%$ level.

\section{Empirical results}

Before conducting the simulation, we first estimate equations (2) and (3). The estimated result of equation (2) is given as:

$$
\begin{aligned}
& \Delta X_{t}=0.0474-0.552 \Delta X_{t-1}-0.226 \Delta X_{t-2} \\
& t-\operatorname{val}(2.506)(-4.234) \quad(-1.717) \\
& +0.431 \Delta B_{t-1}+\varepsilon_{3 t} \\
& \text { (1.186) } \\
& R^{2}=0.251 \\
& \hat{\sigma}=0.091 \\
& \text { Breusch - Godfrey(BG) test } \\
& =0.737(P-\text { value }, 0.539)
\end{aligned}
$$

where $\varepsilon_{3 t}$ is the residual, i.e. the estimated disturbance for period t. The simulated values for $\Delta B_{t}$ and $\Delta X_{t}$ were calculated for 60 periods using equation (1) and (5), with the initial conditions equal to the 1994:Q2 values and with $\varepsilon_{3 t}$ values fed in as the shock estimates for each period. Table 2 reports the results of this simulation exercise with the different $\lambda$ values. The study uses RMSE to choose the $\lambda$ value to verify if McCallum rule can be a guideline for Chinese monetary policy.

Since a smaller RMSE means a better performance, the RMSE values in Table 2 suggest that adopting McCallum rule (1) or rule (2) would have dramatically improved the macroeconomic performance, comparing to the actual performance in the absence of following a rule. Furthermore, using the nominal GDP growth rate of the most recent quarter in the rule's final term, $R M S E\left(\Delta X^{*}-\Delta X\right)$ increases when $\lambda$ increases (point of the sentence?). We obtained similar results when the average nominal GDP growth rate over the past 4 quarters is included in the rule's final term. Rule (2) is slightly superior to rule (1). Next, we check the performance of McCallum rule in the macroeconomic condition specified in equation (6) - the regression result of equation (3), so that we can robustly identify which rule is better and what value to assign to $\lambda$.

$$
\begin{aligned}
& \Delta X_{t}=0.0470-0.5689 \Delta X_{t-1}-0.2635 \Delta X_{t-2} \\
& t \text {-value (2.509) (-4.388) (-1.987) } \\
& +0.4863 \Delta B_{t-1}+0.345 S_{t-1}+\varepsilon_{4 t} \\
& \text { (1.302) (0.701) } \\
& \hat{\sigma}=0.091 \quad R^{2}=0.27 \\
& \text { BG test }=0.401(P-\text { value }, 0.529)
\end{aligned}
$$


periods, with the actual 1994:Q2 values as the initial conditions and with the $\varepsilon_{4 t}$ values fed in as the shock estimates for each period. Table 3 presents the simulation results.

Comparing the $R M S E\left(\Delta X^{*}-\Delta X\right)$ value in Table 3, we find that the macroeconomic performance greatly improved by adopting a policy rule. In addition, the value for $\operatorname{RMSE}\left(\Delta X^{*}-\Delta X\right)$ ascends when $\lambda$ increases, regardless of rule (1) or rule (2) being adopted, and rule (2) is slightly superior to rule (1) when $\lambda$ is bigger than 0.2 .

The simulated results in Table 2 and 3 clearly show that adopting McCallum rule could significantly improve Chinese monetary policy performance. To identify the stability property of the rule with different values for $\lambda$, we depict the target GDP growth rate together with simulated GDP growth rates in Figures 1, 2, 3 and 4. Explosive oscillation does not appear, but the band of oscillation gets wider with an increase in the value of $\lambda$ as shown in the four figures. The improved base rule is slightly better than the original base rule as a monetary policy guideline. Thus, for the stability of nominal economic growth, we decide on rule (2) as Chinese monetary policy guideline with $\lambda=2$, which is similar to McCallum results based on US data (1987, 1988, 1993). When $\lambda=0.2$, the original and improved rules produce equal $\operatorname{RMSE}\left(\Delta X^{*}-\Delta X\right)$ in macroeconomic condition specified by equation (6), and produce approximately equal $R M S E\left(\Delta X^{*}-\Delta X\right)$ in condition specified by equation (5).

This study has demonstrated how well McCallum rule could describe China's monetary policy using a counterfactual simulation method. Next, we follow Stuart (1996) and Taylor (1999) historical analysis method to further assess whether McCallum rule would have provided useful information about the policy stance in specific economic situations. We test whether past policy errors can be identified by observing the divergence of actual policy from the paths implied by the rule based on historical data (rather than simulation). This method looks at the trend in actual policy rather than to compare point estimates. Figure 5 shows the path for actual historical monetary base quarterly growth rate and the path for the rule-specified (rule (2) where $\lambda=0.2$ ) monetary base quarterly growth rate between 1994:Q2 and 2009:Q1.
The actual monetary base growth rate showed an upward trend between 1995:Q1 and 1996:Q4, but the rule-specified base growth rate displayed a downward trend (see Figure 5). During this period, China experienced high annual inflation rates, 16.9 and 8.3 percent in 1995 and 1996 respectively. Between 1997:Q1 and 2001:Q4, the actual base growth rate in most cases is below the rule generated base growth rate, and in many occasions, the actual momentary base growth rate demonstrates negative values. During this period, China experienced a deflation with an annual inflation rate of $-0.8,-1.4,0.3$, and 0.5 percent in the four years, respectively. During the period 2003 to 2008, the actual base growth rate is above the rule-specified base growth rate in most cases. Inflation rate ascended and reached $5.9 \%$ in 2008 . The actual monetary base growth rate oscillates around the rulespecified growth rate during the study period. Using McCallum rule as a benchmark, when China's monetary policy is too restrictive, the Chinese economy experienced deflation problem; when the actual policy is too expansionary, the Chinese economy ran into an inflation cycle.

The peaks and troughs of the actual monetary base growth rates in Figure 5 result from the policy adjustments shocks. The Chinese government implemented a tight monetary policy to reduce high inflation from the second half of 1993. Following a successful control over the price level and the local government investment impulse in the first half of 1996, a relatively expansionary policy was adopted by lowering the benchmark interest rate in May 1996. The first peak appeared in 1996:Q3 is regarded as the rebound of money supply. The second peak appeared in 1998:Q1 is the result of a series of policy actions to stimulate the economy, such as removal of the imposition on credit rationing in state-owned commercial banks, and performing more open market operations to increase money supply.

The transitory effect followed by a trough in 1998:Q2 results from a dramatically decrease in China export demand and therefore the aggregate demand. After four years of deflation, increase in government investment in infrastructure and real estate as well as the increase in the official wages led to the third peak at the beginning of 2002. Another trough appears in 2002:Q2 because of the call-back adjustment and the rise in the rate of reserve requirement in June 2002. From then on, the Chinese economy recovered and started a gradual increase in price level. The big gap between the actual monetary base growth rate 
and the rule-generated monetary base growth rate during the 2006:Q2 - 2008:Q3 is the result of expansionary monetary policy (the negative real deposit interest rates) and the increasing funds outstanding for foreign exchange. Chinese foreign exchange reserve increased from US\$ 9,411.15 billions to US\$ 19,055.85 billions during the 2006:Q2 - 2008:Q3.

\section{Conclusion}

This study employs the counterfactual simulation method to verify whether McCallum rule could be used as a monetary policy guideline for China during the period 1994:Q1 through 2009:Q1. To confirm the robustness of our empirical results, we employ two simple macroeconomic models to specify the macroeconomic conditions for the rule to operate. The first model followed the McCallum framework, and the second is a revised model with exchange rate variable taking into consideration the influence of China's managed floating exchange rate regime on monetary policy.

The study simulated monetary base growth and the nominal GDP growth paths. The simulation results show the $R M S E\left(\Delta X^{*}-\Delta X\right)$ between the target nominal GDP growth rate and the simulated nominal GDP growth rate is much smaller than the target nominal GDP growth rate and actual historical nominal GDP growth rate. With similar value for monetary policy response factor, the performance of the improved rule is slightly better. A smaller value for the monetary response factor in McCallum rule is more appropriate in the case of China. The simulated nominal GDP growth rate is much closer to the target nominal GDP growth rate with a smaller monetary response factor than with a bigger monetary response factor. Bigger monetary response factor results in wider economic growth oscillation. In addition, this study followed Stuart (1996) method to check the validity of McCallum rule as a monetary policy guideline in China. The result shows the rule-specified path of monetary base growth rate could be a monetary policy guideline for China. Therefore, we recommend the PCB's could use McCallum rule as an illustrative benchmark instead of strictly following the simple McCallum rule. According to Taylor (2000b) and McCallum's (2002b, p.1) studies, a central bank should not mechanically follow a policy rule in a "mechanical-looking algebraic form. Instead, policy makers should use the rule as a policy guideline or benchmark in making policies.
A limitation in our study is the use of a single equation to specify the macroeconomic condition to evaluate the feasibility of McCallum rule as a monetary policy guideline for China. A possible extension of this study is to evaluate McCallum rule in structural models that specify more complex macroeconomic situation for the rule to operate. The extension can complement results in this study and further verify the robustness of this study results. Another limitation is that we do not utilize a constant value for the nominal GDP target variable, as McCallum rule has specified. This is because the Chinese government announces a real GDP target and a price level target every year and the values change from time to time. 


\section{References}

Bank for International settlement Statistics,http://www.bis.org/statistics/eer /index.htm

Barro, Robert, and David Gordon, 1983, Rules, Discretion, and Reputation in a Model of Monetary Policy. Journal of Monetary Economics, Vol. 12, P101-122

Blinder Alan S., 1998, Central Banking in Theory and Practice, The MIT Press.

Burdekin, Richard C.K. and Pierre L. Siklos, 2005, What Has Driven Chinese Monetary Policy Since 1990? Investigating the People's Bank's Policy Rule, East-West Center Working Papers, No. 85

Clark Todd E, 1994, Nominal GDP Targeting Rules: Can They Stabilize the Economy? Economic Review, Federal Reserve Bank of Kansas City, Quarter 3

Cochrane John H. 2007, Identification With Taylor Rules: A Critical Review. NBER working paper, No. 13410

Duker Michael J., 1993, Can Nominal GDP Targeting Rules Stabilize the Economy? Fed Reserve Bank of St. Louis Review, May. P15-29

Friedman, M. 1959. A Program for Monetary Stability, New York: Fordham University Press.

Hafer R. W. Haslag J. H. and Scott E. Hein, 1991, Evaluating Monetary Base Targeting Rules, Southern Illinois University Working Paper, No. 9104

Hafer R. W. Haslag J. H. and Scott E. Hein, 1996, Implementing Monetary Base Rules: The Currency Problem, Journal of Economics and Business, Vol. 48, Issue, 5, p 461-472.

Hall Thomas E. 1990, McCallum's Base Growth Rule: Results for the United States, West Germany, Japan and Canada, Weltwirtschaftliches Archiv, Vol. 126, p 630-642

International Financial statistics, http://www.imfstatistics.org/imf/

Judd, John P. and Brian Motley, 1991, Nominal Feedback Rules for Monetary Policy, Economic Review, Federal Reserve Bank of San Francisco, summer, No. 3.

Judd, John P. and Brian Motley, 1993, Using a Nominal GDP Rule to Guide Discretionary Monetary Policy, Economic Review, Federal Reserve Bank of San Francisco, Number 3, p 3-11.

Kalin Nikolov, 2002, Monetary Policy Rules at the Bank of England, Workshop Paper for the Workshop on the "The Role of
Policy Rules in the Conduct of Monetary Policy” at the European Central Bank, March.

King Robert G. and Plosser Charles I. 1982, The Behavior of Money, Credit and Price in a Real Business Cycle. NBER Working Paper, No. 853

Kong Danfeng, 2008, Monetary Policy Rule for China: 1994-2006. East Asia Economic Research Working Paper, No. 14, University of Queensland

Kydland Finn, and Edward Prescott, 1977, Rules Rather Than Discretion: The Inconsistency of Optimal Plans, Journal of Political Economy, Vol. 85, P473-492

Liu Li-gang and Zhang Wenlang, 2007, A New Keynesian Model for Analyzing Monetary Policy in Mainland China, Hong Kong Monetary Authority Working Paper, 18/2007

Lucas, J; Robert E. 1980, Rules, Discretion, and the Role of the Economic Advisor, Rational Expectations and Economic Policy, Edited by Stanley Fisher, University of Chicago Press, pp. 199-210

McCallum Bennett T. 1984, Monetarist Rules in the Light of Recent Experience, American Economic Review, Vol. 74, No.2, p 388-391.

McCallum Bennett T. 1985, On Consequence and Criticisms of Monetary Targeting. Journal of Money, Credit, and Banking, Vol. 17, p570-97

McCallum Bennett T. 1987, The Case for Rules in the Conduct of Monetary Policy: A Concrete Example. Economic Review, Sep/Oct, 1987

McCallum Bennett T. 1988, Robustness Properties of A Rule for Monetary Policy, Carnegia-Rochester Conference Series on Public Policy, 29, P 173-204.

McCallum Bennett T. 1993, Specification and Analysis of A Monetary Policy Rule for Japan, NBER Working Paper, No. 4449

McCallum Bennett T. 1999, Issues in the Design of Monetary Policy Rules, Handbook of Macroeconomics Edited by J.B. Taylor and M. Woodford, Chapter 23, Vol. 1, p 1483-1530.

McCallum Bennett T.2000, Alternative Monetary Policy Rules: A Comparison with Historical Settings for The United States, the United Kingdom, and Japan. Economic Quarterly of the Federal Reserve Bank of Richmond, 1/86, Winter, p 49-79.

McCallum Bennett T. March 2002a, Monetary Policy rules and the Japanese Deflation, Conference Paper for the March 20, 2002 Workshop Sponsored by the Economic 
and Social Research Institute of the Japanese Government.

McCallum Bennett T. November 2002b, The Use of Policy Rules in Monetary Policy Analysis. Shadow Open Market Committee.

McCallum Bennett T, 2006, Policy-Rule Retrospective on the Greenspan Era. Shadow Open Market Committee, Manuscript, May 8.

Melter Allan H. 1995, Monetary, Credit and (Other) Transmission Process: A Monetarist Perspective, Journal of Economic Perspectives, Vol. 9, Number 4, p. $49-72$

Philip N. Jefferson, 2000, 'Home' Base and Monetary Base Rules: Elementary Evidence from the 1980s and 1990s. Journal of Economics and Business, 52, p 161-180.

Razzak W. A. 2003, Is The Taylor Rule Really Different From The McCallum Rule? Contemporary Economic Policy, Vol. 21, No. 4, p 445-457.

Simons, Henry C. 1936. Rules versus Authorities in Monetary Policy, The Journal of Political Economy, Vol. 44, P1-30

Sims Christopher, 1980, Comparison of Interwar and Postwar Business Cycles: Monetarism Reconsidered, NBER Working Paper No.430

Stark Tom and Dean Croushore, 1996, Evaluating McCallum's Rule When Monetary Policy Matters, Federal Reserve Bank of Philadelphia working paper, No. 96-3

Stuart Alison, 1996, Simple Monetary Policy Rules, Bank of England Quarterly Bulletin, August. P 281-287.
Taylor B. John, 1993, Discretion versus Policy Rules in Practice, Carnegie-Rochester Conference Series on Public Policy, 39, p195-214.

Taylor Johan B., 1998, Monetary Policy Guidelines for Employment and Inflation Stability, Inflation, Unemployment, and Monetary policy. The MIT Press, p. 45

Taylor John B., 1999, A Historical Analysis of Monetary Policy Rules, In Monetary Policy Rules, edited by John B. Taylor, University of Chicago Press.

Taylor John B., 2000a, Using Monetary Policy Rules in Emerging Market Economies, Stanford University Manuscript.

Taylor John B., 2000b, Recent Developments in the Use of Monetary Policy Rules, Speech at the Conference "Inflation Targeting and Monetary Policies in Emerging Economies" at the Central Bank of the Republic of Indonesia, July 13-14

Taylor John B. 2001, The role of the Exchange Rate in Monetary Policy Rules, The American Economic Review, May, 91, p, 263-267.

The People's Bank of China Quarterly Statistical Bulletin, 1996, Vol. 1

Tuuli Koivo, 2008, Has the Chinese Economy Become More Sensitive to Interest Rate? Studying Credit Demand in China, China Economic Review, XXX, 2008, p1-16.

Tuuli Koivu, Aaron Mehrotra and Riikka Nuutilainen, 2008, McCallum Rule and Chinese Monetary Policy, BOFIT Discussion Papers, 15

Beck Gunter B. and Weiland Volker, 2008, Central Bank Misperceptions and the Role of Money in Interest Rate Rules. European Central Bank Working Paper Series, No. 967, November 2008 
Table 1 Result of Unit Root Test

\begin{tabular}{llllll}
\hline Variable & $(\mathrm{C}, \mathrm{T}, \mathrm{K})$ & ADF-test & $1 \%$ & $5 \%$ & $10 \%$ \\
$\Delta B$ & $(\mathrm{C}, 0,2)$ & -2.6812 & -3.522 & -.2 .9017 & $-2.5882^{*}$ \\
$\Delta V B$ & $(\mathrm{C}, 0,2)$ & -2.9514 & -3.548 & $-2.9126^{* *}$ & -2.5940 \\
$\Delta X$ & $(\mathrm{C}, 0,0)$ & -13.3297 & $-3.520^{* * *}$ & -2.9006 & -2.5876 \\
$\Delta S$ & $(\mathrm{C}, 0,0)$ & -5.2241 & $-3.546^{* * *}$ & -2.9117 & -2.5935 \\
\hline Variable & $(\mathrm{C}, \mathrm{T}, \mathrm{B})$ & PP-test & & $1 \%$ & \\
$\Delta B$ & $(\mathrm{C}, \mathrm{T}, 5)$ & -7.5523 & & $-3.5203^{* * *}$ & \\
$\Delta V B$ & $(\mathrm{C}, \mathrm{T}, 3)$ & -4.0416 & & $-3.5460^{* * *}$ & \\
\hline
\end{tabular}

C, T, K, B stands for constant, linear trend, the lag-length (based on SIC), bandwidth (NeweyWest using Barlett Kernel) respectively ***, **,* stands for 1, 5, 10 per cent significant level respectively. 
Table 2. Simulation Results (using Equation (5))

\begin{tabular}{|c|c|c|c|c|c|c|c|}
\hline \multicolumn{3}{|l|}{ Policy } & \multicolumn{5}{|c|}{$R M S E\left(\Delta X^{*}-\Delta X\right)$} \\
\hline \multicolumn{2}{|c|}{ Actual Historical } & \multicolumn{6}{|l|}{0.10168} \\
\hline \multirow[t]{2}{*}{ Rule (1) } & $\lambda=0$ & $\lambda=0.1$ & $\lambda=0.2$ & $\lambda=0.3$ & $\lambda=0.5$ & $\lambda=0.7$ & $\lambda=1$ \\
\hline & 0.02102 & 0.02104 & 0.02114 & 0.02131 & 0.02192 & 0.02293 & 0.02561 \\
\hline Rule (2) & & 0.02100 & 0.02107 & 0.02121 & 0.02174 & 0.02256 & 0.02427 \\
\hline
\end{tabular}

Rule (1) refers to the rule using the lag-one nominal GDP value in the final term.

Rule (2) uses the average nominal GDP growth rate over the past four quarters. 
Table 3. Simulation Results (using Equation (6))

\begin{tabular}{lccccc}
\hline Policy & \multicolumn{3}{c}{$R M S E\left(\Delta X^{*}-\Delta X\right)$} \\
\hline Actual Historical & 0.10168 & & \\
\hline Rule (1) & $\lambda=0$ & $\lambda=0.2$ & $\lambda=0.5$ & $\lambda=0.7$ & $\lambda=1$ \\
& 0.0225 & 0.0228 & 0.0240 & 0.0255 & 0.0301 \\
\hline Rule (2) & 0.0225 & 0.0228 & 0.0238 & 0.0250 & 0.0272 \\
\hline
\end{tabular}

Rule (1) refers to the rule using the lag-one nominal GDP value in the final term.

Rule (2) uses the average nominal GDP growth rate over the past four quarters. 
Figure 1. Results from simulation with alternative values of $\lambda$ for rule (1) using equation (5)
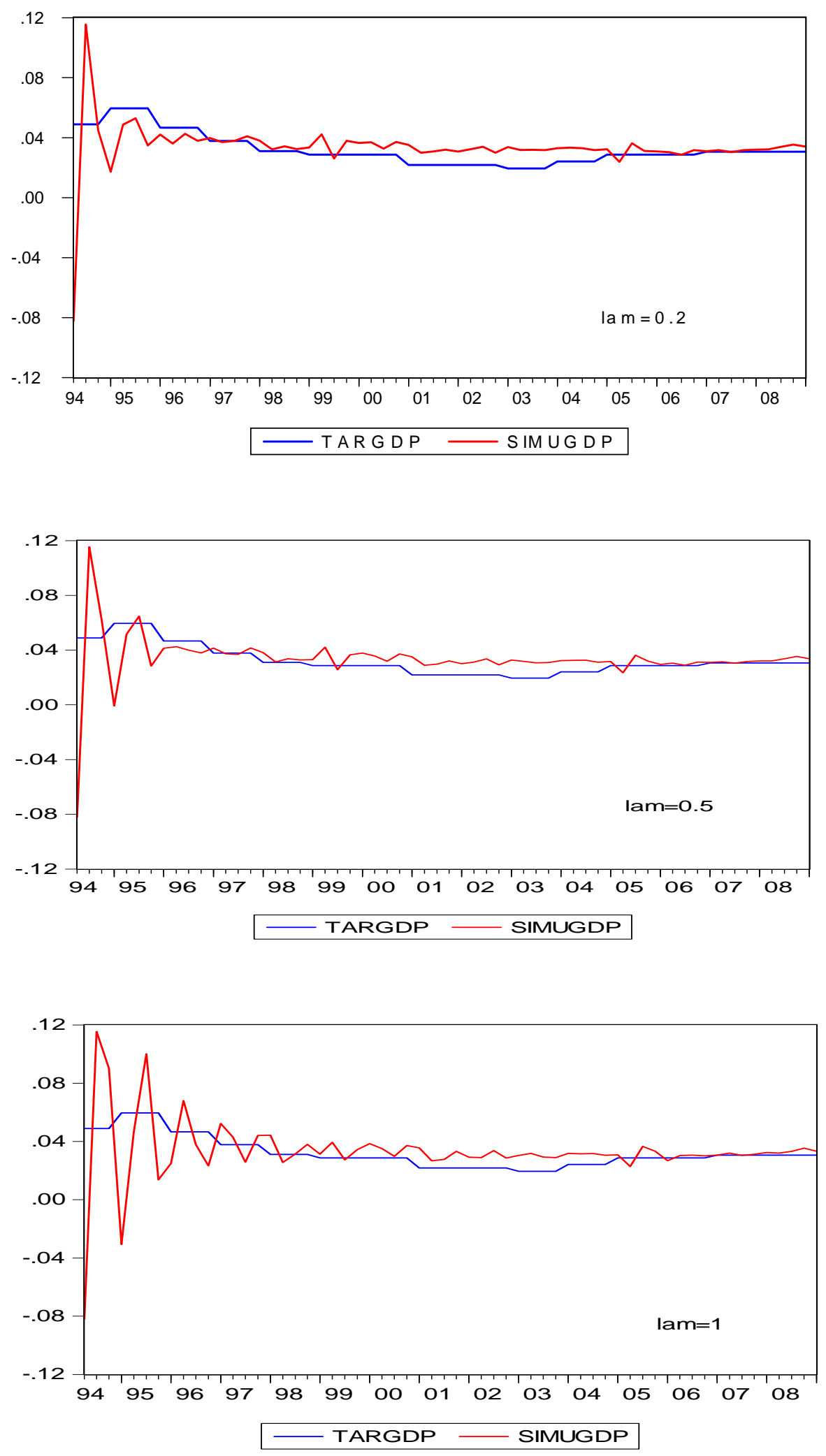
Figure 2. Results from simulation with alternative values of for rule (2) using equation (5)
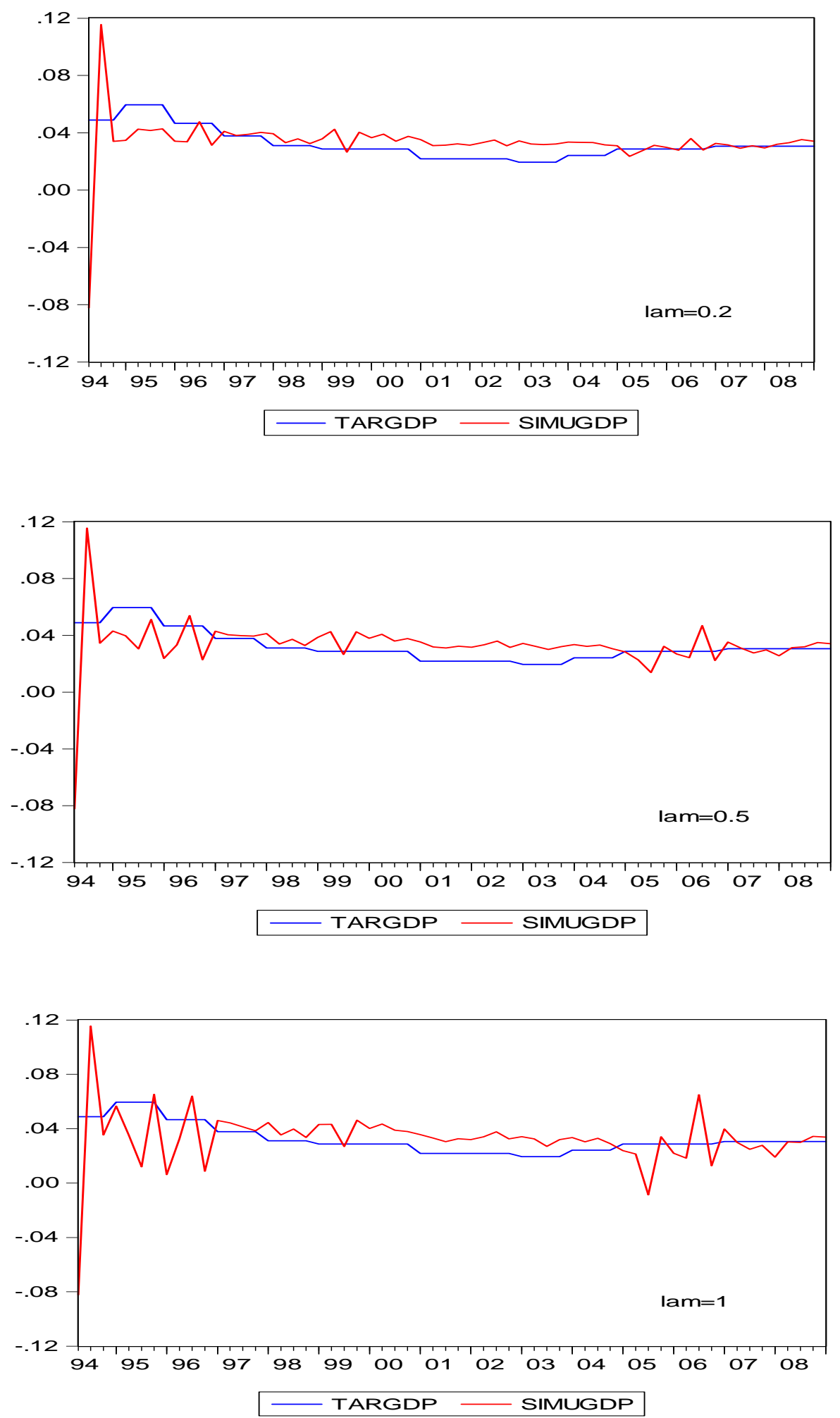
Figure 3. Results from simulation with alternative values of for rule (1) using equation (6)
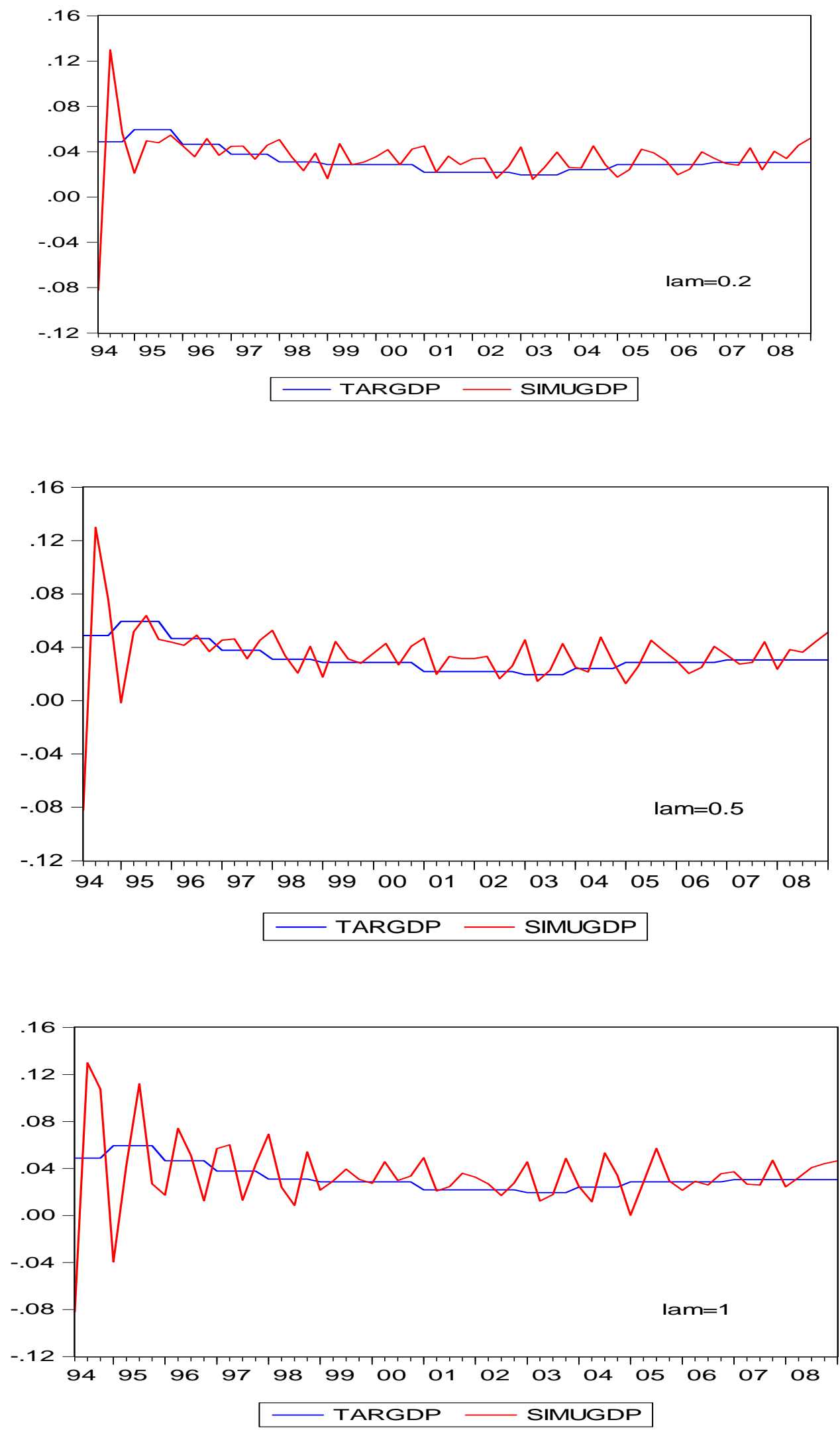
Figure 4. Results from simulation with alternative values of for rule (2) using equation (6)
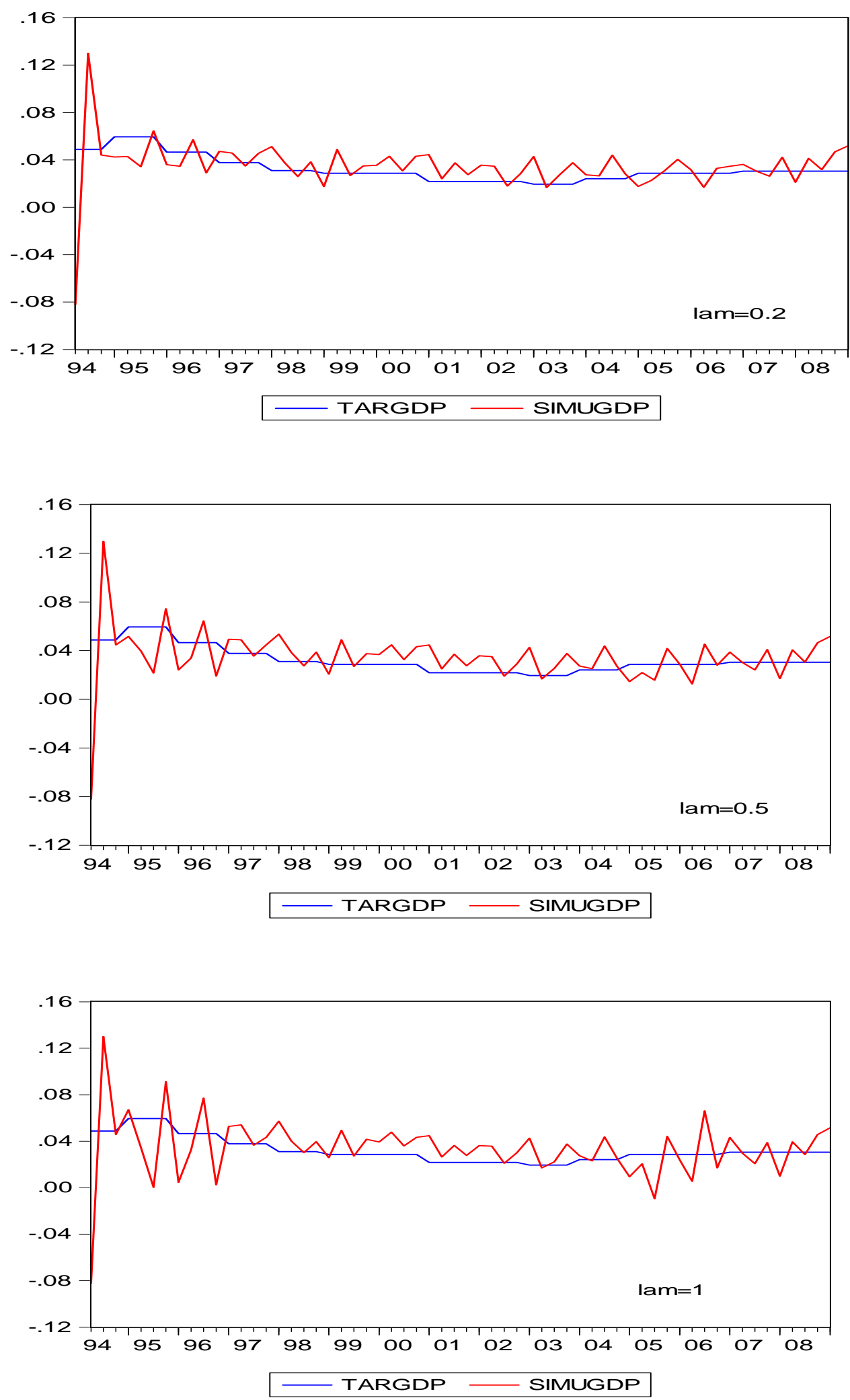
Figure 5. McCallum Rule for Monetary Base

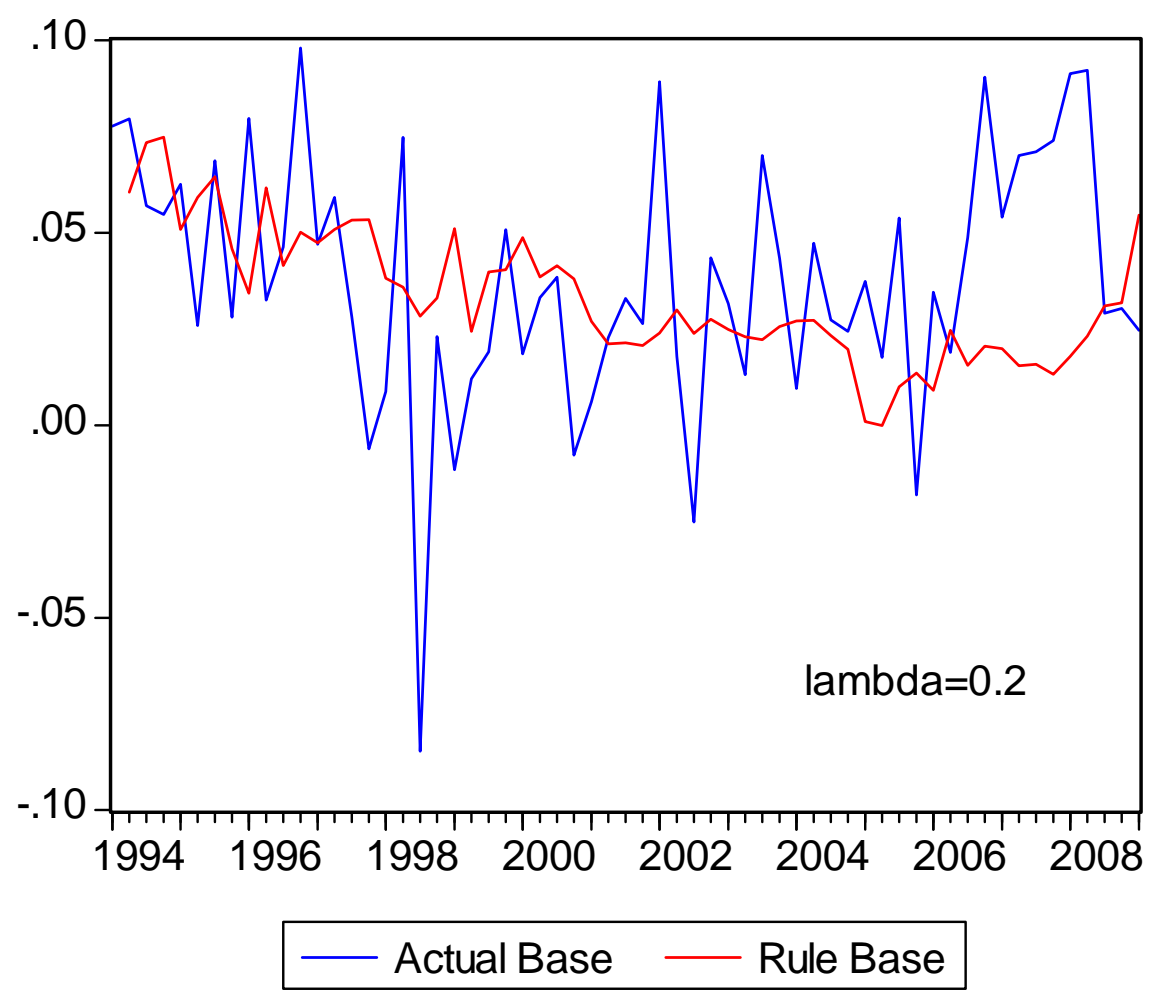

